\title{
Study of the properties of non-gas dielectric capacitors in porous media
}

\author{
Hong-Qi Liu $\cdot$ Yan Jun $\cdot$ You-Ming Deng
}

Received: 2 April 2014/Published online: 1 February 2015

(c) The Author(s) 2015. This article is published with open access at Springerlink.com

\begin{abstract}
The size of pores and throats is at the nanometer scale in tight oil and shale gas zones, and the resistivity of these reservoirs is very high, so the reservoirs show more dielectric properties than conductivity properties. The conductive and dielectric characteristics of a parallel plate capacitor full of fresh water, $\mathrm{NaCl}$ solutions, and solid dielectrics, for example, sands are investigated in this paper, and the capacitance data of the non-gas capacitor are measured at different salinities and frequencies by a spectrum analyzer. The experimental results illustrate that the capacitance of this kind of capacitor is directly proportional to the salinity of the solutions and inversely proportional to the measuring frequency, the same as a vacuum parallel plate capacitor. The remarkable phenomenon, however, is that the capacitance is inversely proportional to the square of the distance between two plates. The specific characteristic of this capacitor is different from the conventional parallel plate capacitor. In order to explain this phenomenon, the paper proposed a new concept, named "single micro ion capacitor", and established a novel model to describe the characteristics of this particular capacitor. Based on this new model, the theoretical capacitance value of the single micro ion capacitor is
\end{abstract}

H.-Q. Liu ( $₫)$ · Y.-M. Deng

State Key Laboratory of Oil and Gas Reservoir Geology and

Exploitation, Southwest Petroleum University,

Chengdu 610500, Sichuan, China

e-mail: lhqjp1@126.com

Y. Jun

Centrica Energy (E\&P) Upstream Kings Close, 62 Huntly Street, Aberdeen AB 101 RS, UK

Edited by Jie Hao calculated, and its polarization and relaxation mechanisms are analyzed.

Keywords $\mathrm{NaCl}$ solution $\cdot$ Debye model $\cdot$ Single micro ion capacitor - Dielectrics · Micro capacitivity

\section{Introduction}

As we know, rocks have both conductive and dielectric properties. The conductivity is completely determined by various anions and cations, such as $\mathrm{Na}^{+}, \mathrm{Mg}^{2+}, \mathrm{Ca}^{2+}, \mathrm{K}^{+}$, $\mathrm{Cl}^{-}, \mathrm{OH}^{-}, \mathrm{HCO}_{3}{ }^{-}, \mathrm{SO}_{4}{ }^{2-}$, and $\mathrm{CO}_{3}{ }^{2-}$ in water solution in the intergranular pores of rocks. Which property of the rocks will play a predominant role depends on the salinity, porosity, permeability, and the geometric structure of the pores. In fact, almost all substances in nature are dielectrics, and only a few have conductivity $(\sigma)$ (Havriliak and Negami 1966). The conductive paths of these charges are usually continuous in relatively high porosity and high permeability reservoirs, but in most occasions, they are discontinuous in tight oil and shale gas zones, or in the low porosity and low permeability reservoirs (Gasparrini et al. 2014; Ghanizadeh et al. 2014). Therefore, the electric properties of rocks include two major aspects: one is the conductive capability of free positive and negative charges in the water solution through the paths formed by pores and throats which connected with each other; the other is the dielectric capability of the bound charges of the non-conductive substances and particles, including rock matrix particles, oil or gas molecules, and pure water molecules (Freedman and Vogiatzis 1979; Jonscher 1983; Endres and Bertrand 2006). Nevertheless, whether conductive or dielectric, the current paths in the formation are influenced by the geometric pore structure of rocks. The relationship 
between the conductive and dielectric properties of rocks and the pore structure has been widely discussed in detail in the literature (Toumelin and Torres-Verdin 2009), so it is not described here. Prior to 1940, studies on the electrical properties of rocks mainly focused on conductivity. In 1941, K. S. Cole and R. H. Cole established the Cole-Cole model for dielectric constants (Cole and Cole 1941); later, many scholars studied ionic conduction and rock polarization processes, analyzing the dielectric constant property of non-homogeneous multi-pore materials (Hilfer et al. 1995, 1999; Nover et al. 2000; Ruffett et al. 1991; Davidson and Cole 1950, 1951).

With regard to the electrical logging technology in the petroleum industry, almost all research has focused on the detection and interpretation of formation resistivity. However, more and more complex and unconventional reservoirs have been discovered, and the traditional, simple geophysical conductive model cannot solve the problems of strongly heterogeneous reservoirs, such as low porosity and low permeability oil reservoirs, tight oil zones, and shale gas zones. Although scholars have proposed various solutions and models for some important questions to describe the electrical conductivity mechanism in rocks (Chelidze and Gueguen 1999; Chelidze et al. 1999; Asami 2002), it is increasingly difficult to accurately determine fluid types and calculate the saturation of hydrocarbon. In 1988, Clark et al. proposed an electromagnetic propagation tool (EPT) to measure the dielectric constant of the formation at frequencies of $2 \mathrm{MHz}-1.1 \mathrm{GHz}$ (Glover et al. 1994a, b, 1996; Clark et al. 1990). This method can identify fluid types and calculate the fluid saturation in high porosity and high permeability reservoirs. Dong and Wang (2009) studied the dielectric constant of several common minerals, including quartz, calcite, and dolomite, within a frequency range from $\mathrm{Hz}$ to $\mathrm{GHz}$ level, and they identified pore structures and the distribution of formation water using the dielectric constant. In 1985, Lockner and Byerlee (1985) studied the complex resistivity of rocks; later, other scholars also studied the complex resistivity of rocks. However, due to the extraordinarily complex heterogeneity of porous rocks, there are still many disputes over the conductive and dielectric mechanisms in rocks (Clavier et al. 1984; Zemanek 1989; Hamada and Al-Awad 1998). Scholars have proposed many conductive models for rocks, of which the most representative is the dual-water argillaceous sandstone conductive model proposed by Waxman and Smits in 1968 (Waxman and Smits 1968; Knight and Nur 1987; Hassoun et al. 1997).

\section{Micro ion capacitor model}

Obviously, the conductive and dielectric capabilities of rocks depend on the amount of different positive and negative ions dissolved in water solution. Generally, these different ions can be equivalent to $\mathrm{Na}^{+}$and $\mathrm{Cl}^{-}$in view of their conductive property. Therefore, it is crucial to study the conductive and dielectric properties of $\mathrm{NaCl}$ solutions (Jonscher 1999; Lesmes and Morgan 2001). The pure water and hydrocarbon molecules cannot conduct current, and the conductive ions are separated from each other by water and hydrocarbon molecules, as shown in Fig. 1. So the solution in the pores can be regarded as a mixture of non-conductive molecules and conductive free ions (Fig. 2). Considering the water and hydrocarbon molecules as non-conductive land, the $\mathrm{Na}^{+}$and $\mathrm{Cl}^{-}$ions are an isolated conductive river separated by this land, and the ion river moves through this land in a tortuous path. Then a model with "ion flux" and "molecule land" can be established to explain the conductive and dielectric mechanisms. In Fig. 1, the yellow or gray blocks denote rock particles of different minerals, the blue parts represent the formation water, the red belts denote hydrocarbons dispersed in the water, which are nonconductive parts; and the green solid ball denotes free $\mathrm{Cl}^{-}$, the red solid ball denotes free $\mathrm{Na}^{+}$, which are conductive parts. Of course, the rock matrix is also non-conductive.

Figure 2 illustrates the distribution of the non-conductive molecules of water and hydrocarbon, and the conductive ions of $\mathrm{Na}^{+}$and $\mathrm{Cl}^{-}$in an external electromagnetic field (EMF). If an alternating EMF, such as $I=I_{0} \sin \left(\omega t+\theta_{0}\right)$, is applied on both sides of rocks, the free ions will be rearranged quickly according to the external EMF, resulting in a regular arrangement of ions. The rearranged ions move directionally under the effect of the external EMF as shown in Fig. 3. These ions gradually move to the ends of mineral grains through pores. Generally the $\mathrm{Cl}^{-}$ions gather at the anode, and $\mathrm{Na}^{+}$ions gather at the cathode. An internal electric field is created in the rock, whose field direction is opposite to the external field. The time of this process depends on the conductive properties of rocks. But after the established relatively stable EMF within a remarkably short

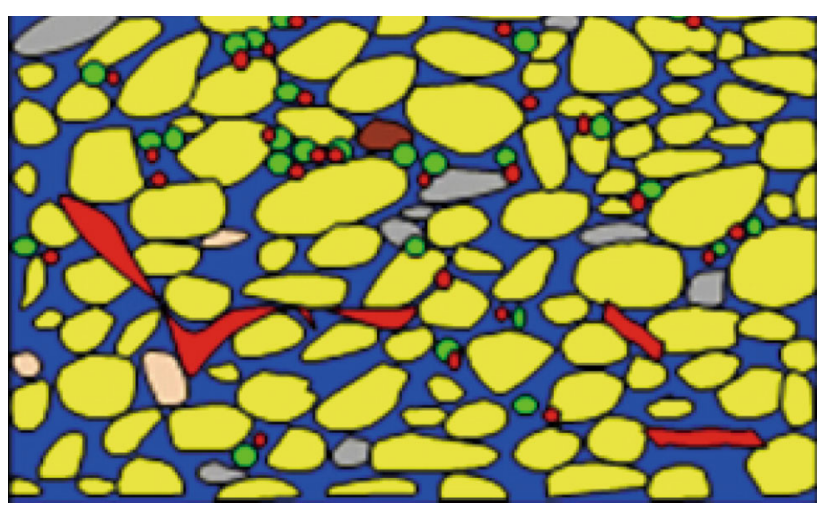

Fig. 1 Schematic diagram of a rock with pure water (blue), hydrocarbon (red belt), and $\mathrm{Na}^{+}$(small red ball) and $\mathrm{Cl}^{-}$(large green ball) in the rock 
Fig. 2 Distribution of the nonconductive water and hydrocarbon molecules and ion flux without external EMF

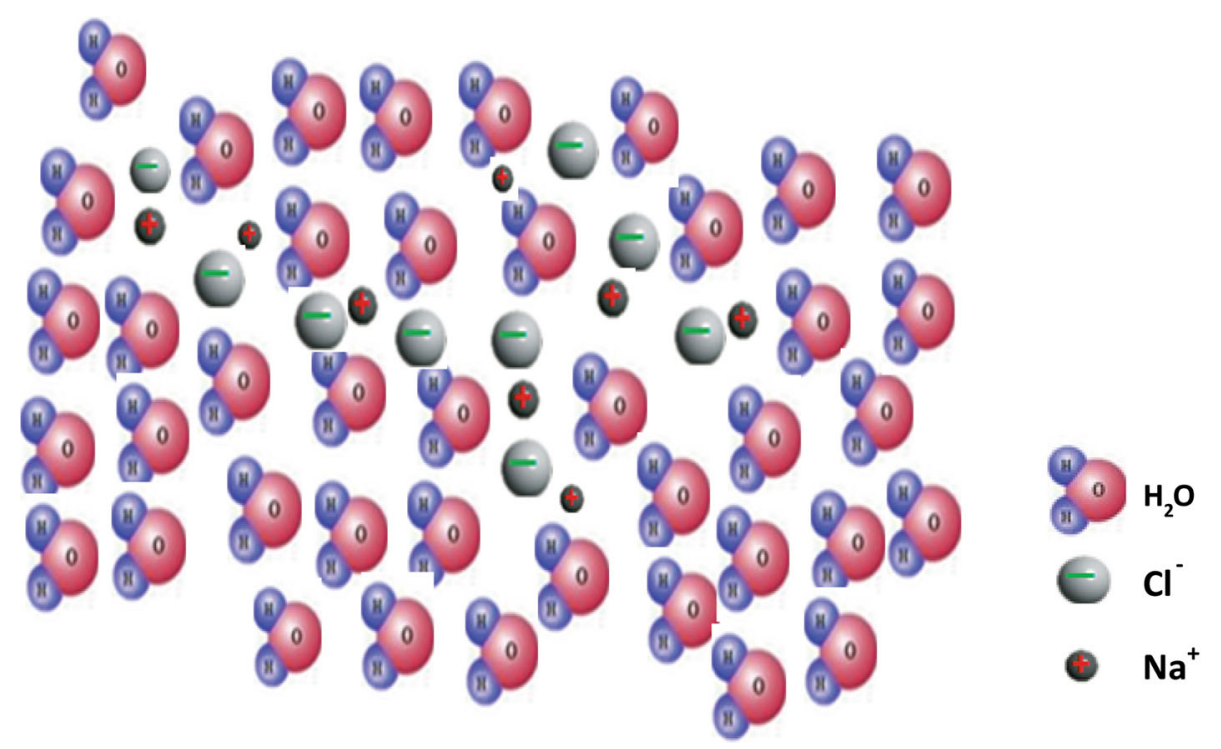

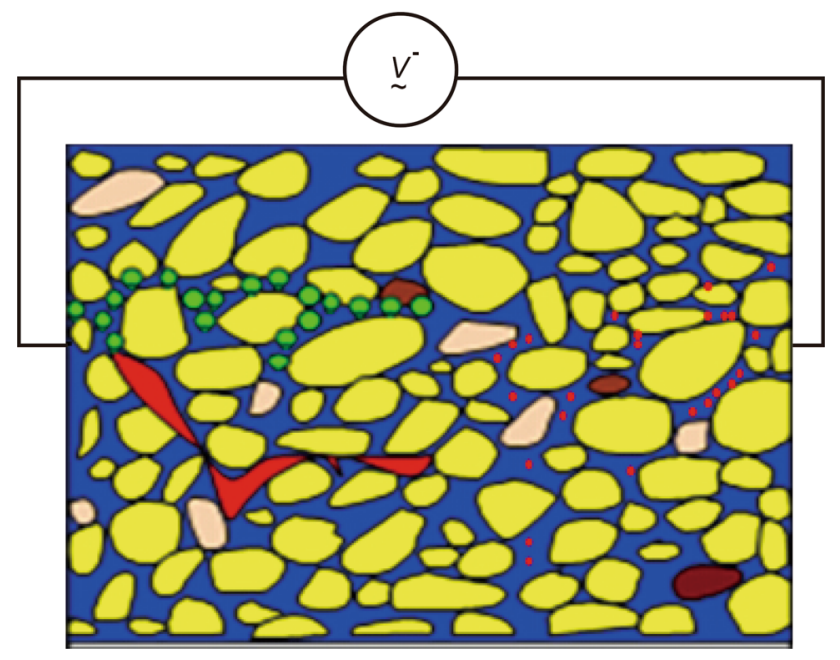

Fig. 3 Schematic diagram of a rock with pure water (blue), hydrocarbon (red belt), and ions traversing through the rock under the influence of an external electromagnetic field (EMF)

time, the amount of free ions in rock pores becomes less and less, and the ions and molecules form a new distribution, as shown in Fig. 4.

The movements of the positive and negative ions result in the establishment of a capacitor. The positive pole is composed of cations, such as $\mathrm{Na}^{+}, \mathrm{Ca}^{2+}, \mathrm{Mg}^{2+}$, and $\mathrm{K}^{+}$, the negative pole is composed of anions, such as $\mathrm{Cl}^{-}, \mathrm{OH}^{-}$, and $\mathrm{SO}_{4}{ }^{2-}$, and the dielectric is water or hydrocarbon molecules. From this moment on, the rocks will show dielectric properties rather than conductivity at the macro level.

The polarization process above, perhaps will not exist in high porosity and especially high permeability reservoirs. As for tight formations, the pore throats are very narrow. For example, when the pores are at the nanometer scale with poor connectivity, the occurring phenomenon is shown in Fig. 5. In tight oil and shale gas zones, several anions and cations respectively gather at the opposite ends of the particle as polar plates like a usual parallel plate capacitor, whereas the non-conductive molecules in the middle are dielectrics, thus a microscopic capacitor, called a "micro ion capacitor", is established. Numerous such micro ion capacitors can be created almost at the same time in the formation, and they may be connected in series or parallel.

\section{Theoretical value of single ion capacitor}

The radii of $\mathrm{Na}^{+}, \mathrm{Cl}^{-}$, and $\mathrm{H}^{+}$ions are $0.95,1.81$, and $2.08 \AA$, respectively. The size of the pore throats in rocks ranges from several to more than 10 microns, and the thickness of the water membrane is less than 1 micron. The space for ion transportation is tens of thousands of times larger than the ion diameter. As shown in Fig. 5, there may be at least tens of thousands of positive and negative ions gathering at the ends of rock particles in the water-wet phase, and a microscopic capacitor is formed with $\mathrm{Na}^{+}$and $\mathrm{Cl}^{-}$ions as two polar plates, with the rock particles wrapped by water membrane with a certain thickness as a dielectric. Although the capacitance of this micro ion capacitor cannot be accurately calculated at present, a theoretical value can be estimated.

If the pores are very small and are not connected, ions are likely to form isolated capacitors with water molecules as dielectric. In case of extreme conditions, a single ion and a single water molecule constitute a micro ion capacitor, as shown in Fig. 6. According to the definition of a capacitor, assuming the voltage of an external EMF is $1 \mathrm{~V}$, the 
Fig. 4 The non-conductive water and hydrocarbon molecules and ions form a micro ion capacitor with an external EMF

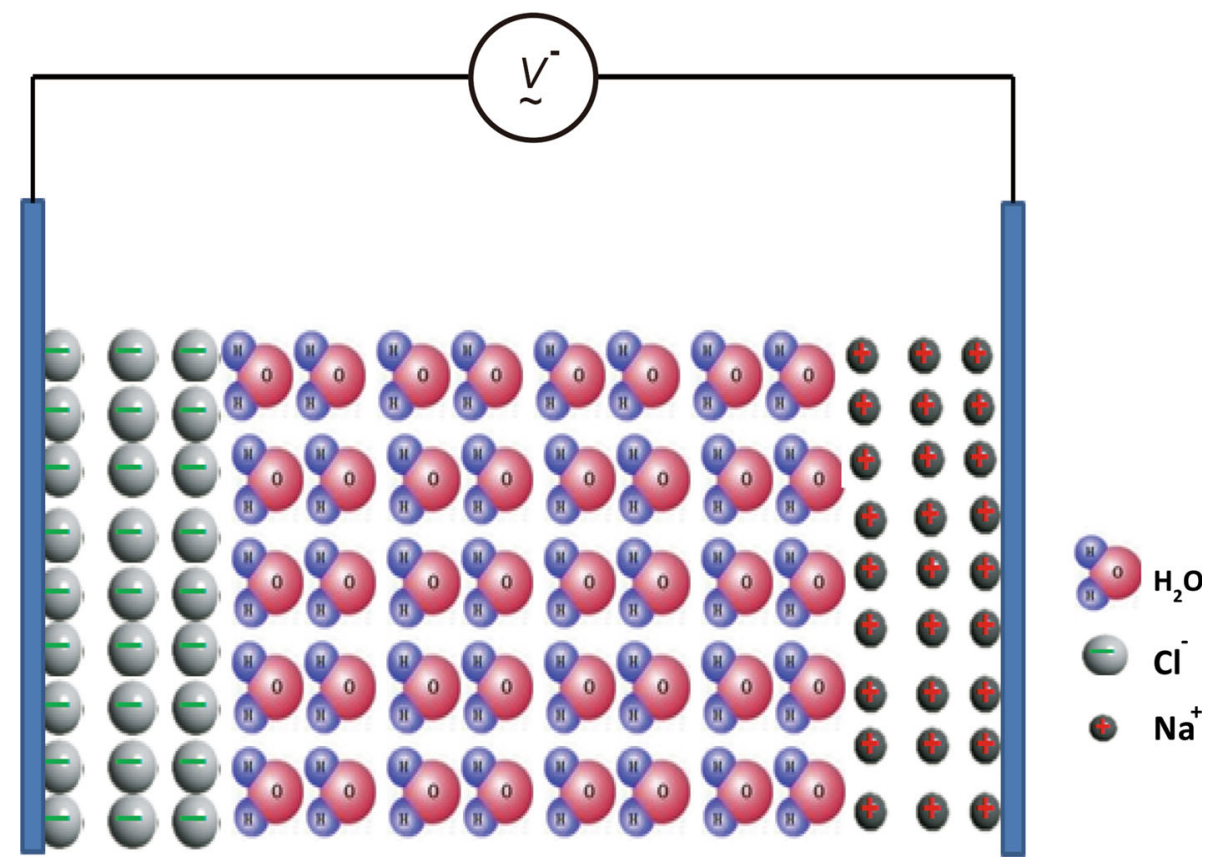

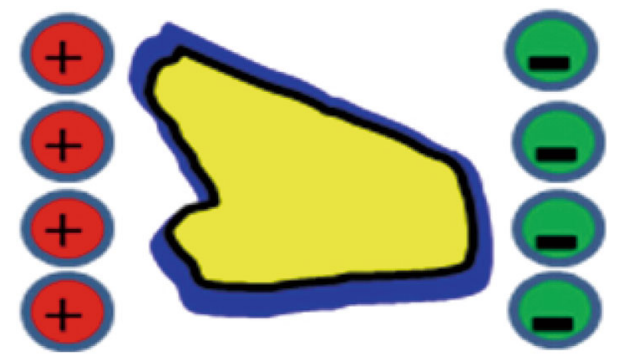

Fig. 5 A single water-wet mineral particle with ions at two sides forming a micro ion capacitor

quantity of the charge for example $\mathrm{Na}^{+}$is $1.6 \times 10^{-19} \mathrm{C}$, then the capacitance of a single ion capacitor is:

$C_{0}=\frac{Q}{V}=\frac{1.6 \times 10^{-19} \mathrm{C}}{1 \mathrm{~V}}=1.6 \times 10^{-19} \mathrm{~F}$

\section{Experiments}

\subsection{Experimental instrument}

Figure 7 illustrates a measuring device using a PVC pipe with a diameter of $2.5 \mathrm{~cm}$ and a length of $150 \mathrm{~cm}$. Two plates were placed, one was fixed on the bottom, the other was movable on the top, and the pipe was full of $\mathrm{NaCl}$ solution. So the resistivity and capacitance of $\mathrm{NaCl}$ solution can be detected at different distances, salinities, and frequencies. One important aspect must be noted that the material of plates should be gold, rather than iron, aluminum, copper, and others, to avoid corrosion by the $\mathrm{NaCl}$ solution.

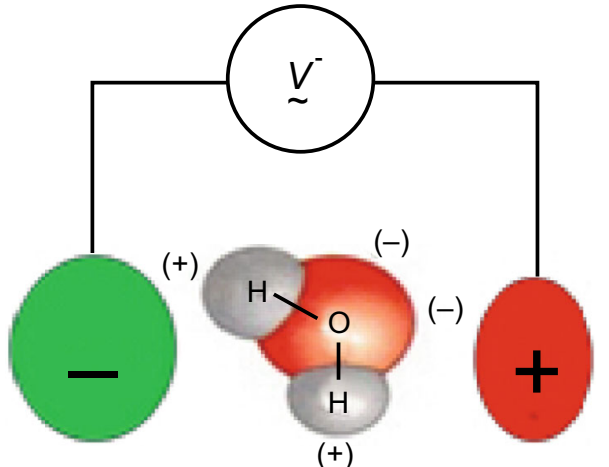

Fig. 6 A single ion capacitor, one sodium ion and one chloride ion respectively as positive and negative plates with a non-conductive $\mathrm{H}_{2} \mathrm{O}$ molecule as media

\subsection{Experimental process}

First, fresh water with different volumes was injected into the PVC pipe, and the upper plate was put at different distances corresponding to the fluid volume. Then the resistance $\left(R_{\mathrm{p}}\right)$ and capacitance $\left(C_{\mathrm{p}}\right)$ were tested with a frequency spectrum analyzer. In this experiment, 12 groups of data were recorded at 12 different distances. At each test point, $R_{\mathrm{p}}$ and $C_{\mathrm{p}}$ were tested at frequencies of $100 \mathrm{~Hz}$ and $1 \mathrm{kHz}$, where the subscript "p" means parallel connection.

Second, $\mathrm{NaCl}$ solution was injected into the same pipe. Then, we repeat the experimental process like that of fresh water, 12 groups of data of $R_{\mathrm{p}}$ and $C_{\mathrm{p}}$ of $\mathrm{NaCl}$ solution with salinities of 0.2 and $1.2 \mathrm{~g} / \mathrm{L}$ were recorded. The capacitance data are listed in Table 1 and resistance data in Table 2. 


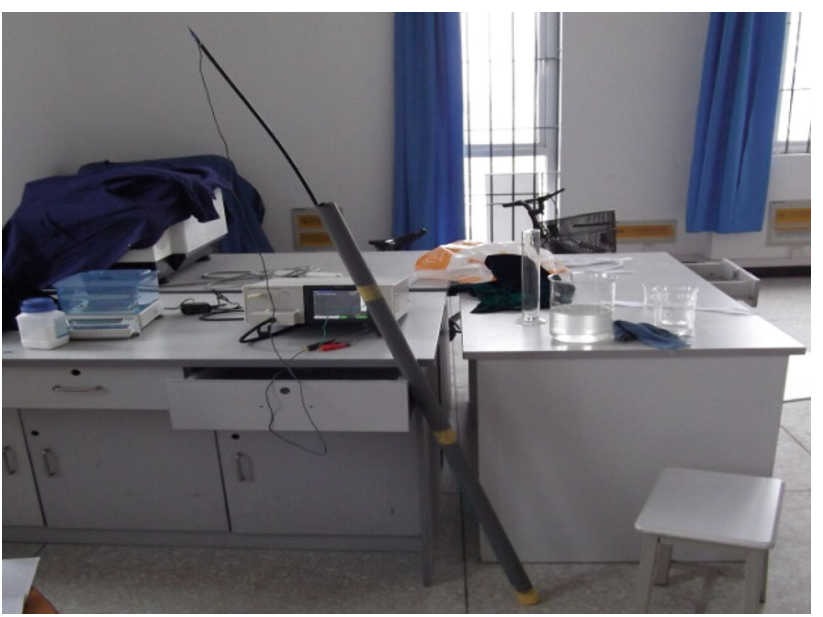

Fig. 7 A PVC pipe with copper wireline and full of $\mathrm{NaCl}$ solution, the dimension is length $\times$ diameter $=150 \mathrm{~cm} \times 2.5 \mathrm{~cm}$

Figure 8 illustrates a plastic container, with a dimension of $17 \mathrm{~cm} \times 5.0 \mathrm{~cm} \times 4.7 \mathrm{~cm}$, filled with sand which is saturated with $\mathrm{NaCl}$ solution. The sand was collected from a river, and was washed many times. Moreover, the sand was filtered by a sorting sieve in order to keep sand almost at the same size. Its mineral composition is mainly quartz. During the experiments, the conditions were changed as follows:

(1) The distance between the polar plates varied from 2 to $17 \mathrm{~cm}$, with eight test points;

(2) The frequency changed from $4 \mathrm{~Hz}$ to $5 \mathrm{MHz}$, with 100 test points, only seven points listed in the tables;

(3) The salinity varied from 1.5 to $200 \mathrm{~g} / \mathrm{L}$, with eight test points.

Table 1 Capacitance $\left(C_{\mathrm{p}}, \mu \mathrm{F}\right)$ at different salinities $(S)$, frequencies $(f)$, and distances $(d)$ in the PVC pipe

\begin{tabular}{|c|c|c|c|c|c|}
\hline \multirow[t]{3}{*}{$d(\mathrm{~m})$} & \multicolumn{5}{|l|}{$S(\mathrm{~g} / \mathrm{L})$} \\
\hline & $\begin{array}{l}\text { Water } \\
f(\mathrm{~Hz})\end{array}$ & 0.2 & 1.2 & 0.2 & 1.2 \\
\hline & 100 & & & $1 \mathrm{k}$ & \\
\hline 0.1 & 970 & 23,500 & 286,000 & 642.0 & 11,200 \\
\hline 0.2 & 252 & 6,170 & 83,800 & 160.0 & 3,010 \\
\hline 0.3 & 112 & 2,730 & 39,900 & 71.0 & 1,340 \\
\hline 0.4 & 61 & 1,550 & 22,500 & 39.0 & 763 \\
\hline 0.5 & 41 & 976 & 15,100 & 24.0 & 491 \\
\hline 0.6 & 25 & 694 & 10,300 & 18.1 & 345 \\
\hline 0.7 & 21 & 510 & 7,730 & 13.0 & 248 \\
\hline 0.8 & 15 & 371 & 5,760 & 10.0 & 192 \\
\hline 0.9 & 12 & 303 & 4,820 & 8.0 & 153 \\
\hline 1.0 & 9 & 241 & 3,740 & 6.0 & 121 \\
\hline 1.1 & 7 & 201 & 3,150 & 5.0 & 98 \\
\hline 1.2 & 6 & 165 & 2,550 & 4.5 & 82 \\
\hline
\end{tabular}

Table 2 Resistance $\left(R_{\mathrm{p}}, \Omega\right)$ at different salinities $(S)$, frequencies $(f)$, and distances $(d)$ in the PVC pipe

\begin{tabular}{|c|c|c|c|c|c|}
\hline \multirow[t]{3}{*}{$d(\mathrm{~m})$} & \multicolumn{5}{|l|}{$S(\mathrm{~g} / \mathrm{L})$} \\
\hline & $\begin{array}{l}\text { Water } \\
f(\mathrm{~Hz})\end{array}$ & 0.2 & 1.2 & 0.2 & 1.2 \\
\hline & 100 & & & $1 \mathrm{k}$ & \\
\hline 0.1 & 23.1 & 3.19 & 0.56 & 3.08 & 0.51 \\
\hline 0.2 & 45.1 & 6.24 & 1.01 & 6.14 & 0.96 \\
\hline 0.3 & 67.45 & 9.35 & 1.47 & 9.25 & 1.43 \\
\hline 0.4 & 90.44 & 12.42 & 1.92 & 12.32 & 1.88 \\
\hline 0.5 & 113 & 15.56 & 2.38 & 15.46 & 2.34 \\
\hline 0.6 & 136 & 18.61 & 2.85 & 18.5 & 2.81 \\
\hline 0.7 & 159 & 21.77 & 3.3 & 21.67 & 3.26 \\
\hline 0.8 & 183 & 24.9 & 3.78 & 24.79 & 3.74 \\
\hline 0.9 & 205 & 27.92 & 4.22 & 27.82 & 4.18 \\
\hline 1.0 & 228 & 31.1 & 4.69 & 30.96 & 4.65 \\
\hline 1.1 & 253 & 34.21 & 5.15 & 34.1 & 5.12 \\
\hline 1.2 & 277 & 37.3 & 5.61 & 37.2 & 5.57 \\
\hline
\end{tabular}

The measurement results of $C_{\mathrm{p}}$ are listed in Table 3 and $R_{\mathrm{p}}$ in Table 4, the distance and frequency changed with a fixed salinity of $1.5 \mathrm{~g} / \mathrm{L}$.

Table 5 lists the capacitance data of sand saturated with $\mathrm{NaCl}$ solution with different salinities and a fixed distance of $17 \mathrm{~cm}$, and Table 6 lists the resistance data of sand saturated with $\mathrm{NaCl}$ solution with different salinities and a fixed distance of $17 \mathrm{~cm}$.

\section{Analysis of experimental results}

5.1 Relationship between conductive and dielectric properties and the distance between plates

Based on the experimental results in the PVC pipe, and the data in Table 1, Fig. 9 demonstrates the characteristics of this capacitor with fresh water and 0.2 and $1.2 \mathrm{~g} / \mathrm{L} \mathrm{NaCl}$ solutions at $100 \mathrm{~Hz}$ and $1 \mathrm{kHz}$. The capacitance changes with different salinities of the solution and different distances between the two plates. Generally, we can conclude as follows:

(1) Under the same conditions, the higher the salinity, the larger the capacitance;

(2) Under the same conditions, the higher the frequency, the lower the capacitance;

(3) Under the same conditions, the capacitance is approximately inversely proportional to the square of the distance.

As shown in Fig. 9, there are five different curves, corresponding to $1.2 \mathrm{~g} / \mathrm{L}$ salinity at $100 \mathrm{~Hz}, 0.2 \mathrm{~g} / \mathrm{L}$ 


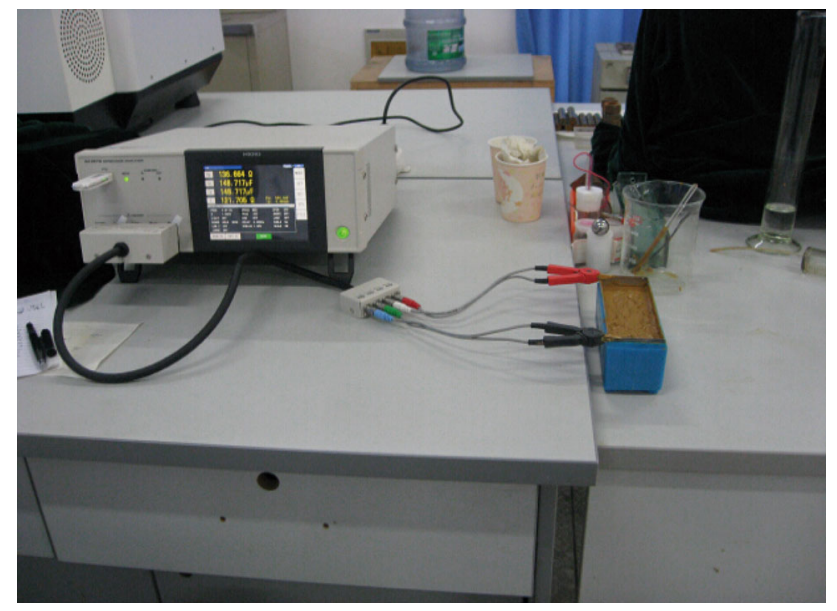

Fig. 8 A plastic container with copper plate and sand saturated with $\mathrm{NaCl}$ solution, the dimension is length $\times$ width $\times$ height $=$ $17 \mathrm{~cm} \times 5.0 \mathrm{~cm} \times 4.7 \mathrm{~cm}$

salinity at $100 \mathrm{~Hz}, 1.2 \mathrm{~g} / \mathrm{L}$ salinity at $1 \mathrm{kHz}$, fresh water at $100 \mathrm{~Hz}, 0.2 \mathrm{~g} / \mathrm{L}$ salinity at $1 \mathrm{kHz}$, respectively. It can be seen that with either the fresh water or the $\mathrm{NaCl}$ solution, either at $100 \mathrm{~Hz}$ or $1 \mathrm{kHz}$, the capacitance is a function of the square of the distance. By the least square method, we know that the distance's exponent of each curve is very close to two. We test it at many different frequencies from
$4 \mathrm{~Hz}$ to $5 \mathrm{MHz}$ and with different salinities, and all of the results prove the same rule, that is, the capacitance is approximately inversely proportional to the square of the distance. Why does this phenomenon occur?

It is well known that the capacitance of a parallel plate capacitor is proportional to the area of the plate $(A)$, and is inversely proportional to the distance between the plates (d), denoted by Eq. (2)

$C=\varepsilon_{0} \frac{A}{d}$

But for the PVC pipe capacitor, according to the definition of capacitance and the rule mentioned above, the equation of $C_{\mathrm{p}}$ can be expressed by

$C_{\mathrm{p}}=\epsilon \frac{A}{d^{2}}$,

where $\epsilon$ is a coefficient. The key point should be noted that $\epsilon$ is not the dielectric constant $\varepsilon_{0}$ because the units of these two parameters are different, and then the physical definition is also different. Based on SI unit, the dimension of $\epsilon$ is $\mathrm{F}$, which is the same as capacitance. Here, we call $\epsilon$ as micro capacitivity.

According to Eq. (3), $\epsilon$ can be expressed as follows:

$$
\epsilon=C_{\mathrm{p}} \frac{d^{2}}{A}
$$

Table 3 Capacitance $\left(C_{\mathrm{p}}, \mu \mathrm{F}\right)$ of sands saturated with $\mathrm{NaCl}$ solution at different frequencies and distances in a plastic container

\begin{tabular}{|c|c|c|c|c|c|c|c|c|}
\hline \multirow[t]{2}{*}{$f, \mathrm{~Hz}$} & \multicolumn{8}{|l|}{$d, \mathrm{~cm}$} \\
\hline & 17 & 15 & 13 & 10 & 8 & 5 & 3 & 2 \\
\hline 4 & $1.40 \mathrm{E}+02$ & $1.79 \mathrm{E}+02$ & $2.39 \mathrm{E}+02$ & $4.22 \mathrm{E}+02$ & $6.37 \mathrm{E}+02$ & $1.60 \mathrm{E}+03$ & $4.41 \mathrm{E}+03$ & $9.88 \mathrm{E}+03$ \\
\hline 10.2 & $7.06 \mathrm{E}+01$ & $8.93 \mathrm{E}+01$ & $1.19 \mathrm{E}+02$ & $2.11 \mathrm{E}+02$ & $3.14 \mathrm{E}+02$ & $8.02 \mathrm{E}+02$ & $2.23 \mathrm{E}+03$ & $5.01 \mathrm{E}+03$ \\
\hline 70.1 & $6.95 \mathrm{E}+00$ & $8.92 \mathrm{E}+00$ & $1.29 \mathrm{E}+01$ & $2.01 \mathrm{E}+01$ & $3.13 \mathrm{E}+01$ & $8.02 \mathrm{E}+01$ & $2.29 \mathrm{E}+02$ & $5.00 \mathrm{E}+02$ \\
\hline 286.8 & $1.40 \mathrm{E}+00$ & $1.79 \mathrm{E}+00$ & $2.38 \mathrm{E}+00$ & $4.01 \mathrm{E}+00$ & $6.04 \mathrm{E}+00$ & $1.58 \mathrm{E}+01$ & $4.36 \mathrm{E}+01$ & $9.74 \mathrm{E}+01$ \\
\hline 1019.1 & $1.87 \mathrm{E}-01$ & $2.42 \mathrm{E}-01$ & $3.15 \mathrm{E}-01$ & $5.38 \mathrm{E}-01$ & $8.31 \mathrm{E}-01$ & $2.14 \mathrm{E}+00$ & $5.41 \mathrm{E}+00$ & $1.32 \mathrm{E}+01$ \\
\hline 5029.1 & $1.40 \mathrm{E}-02$ & $1.70 \mathrm{E}-02$ & $2.30 \mathrm{E}-02$ & $3.80 \mathrm{E}-02$ & $6.10 \mathrm{E}-02$ & $1.57 \mathrm{E}-01$ & $4.34 \mathrm{E}-01$ & $9.81 \mathrm{E}-01$ \\
\hline 10,171 & $3.00 \mathrm{E}-03$ & $4.00 \mathrm{E}-03$ & $6.00 \mathrm{E}-03$ & $1.00 \mathrm{E}-02$ & $1.60 \mathrm{E}-02$ & $4.00 \mathrm{E}-02$ & $1.20 \mathrm{E}-01$ & $2.23 \mathrm{E}-01$ \\
\hline
\end{tabular}

Table 4 Resistance $\left(R_{\mathrm{p}}, \Omega\right)$ of sands saturated with $\mathrm{NaCl}$ solution at different frequencies and distances in a plastic container

\begin{tabular}{|c|c|c|c|c|c|c|c|c|}
\hline \multirow[t]{2}{*}{$f, \mathrm{~Hz}$} & \multicolumn{8}{|l|}{$d, \mathrm{~cm}$} \\
\hline & 17 & 15 & 13 & 10 & 8 & 5 & 3 & 2 \\
\hline 4 & $1.67 \mathrm{E}+02$ & $1.64 \mathrm{E}+02$ & $1.60 \mathrm{E}+02$ & $1.54 \mathrm{E}+02$ & $1.51 \mathrm{E}+02$ & $1.47 \mathrm{E}+02$ & $1.42 \mathrm{E}+02$ & $1.35 \mathrm{E}+02$ \\
\hline 10.2 & $1.17 \mathrm{E}+02$ & $1.13 \mathrm{E}+02$ & $1.08 \mathrm{E}+02$ & $1.01 \mathrm{E}+02$ & $9.65 \mathrm{E}+01$ & $9.17 \mathrm{E}+01$ & $8.86 \mathrm{E}+01$ & $8.66 \mathrm{E}+01$ \\
\hline 70.1 & $7.42 \mathrm{E}+01$ & $6.86 \mathrm{E}+01$ & $6.24 \mathrm{E}+01$ & $5.38 \mathrm{E}+01$ & $4.81 \mathrm{E}+01$ & $4.07 \mathrm{E}+01$ & $3.66 \mathrm{E}+01$ & $3.48 \mathrm{E}+01$ \\
\hline 286.8 & $6.19 \mathrm{E}+01$ & $5.60 \mathrm{E}+01$ & $4.94 \mathrm{E}+01$ & $4.01 \mathrm{E}+01$ & $3.37 \mathrm{E}+01$ & $2.49 \mathrm{E}+01$ & $1.98 \mathrm{E}+01$ & $1.75 \mathrm{E}+01$ \\
\hline 1019.1 & $5.77 \mathrm{E}+01$ & $5.17 \mathrm{E}+01$ & $4.50 \mathrm{E}+01$ & $3.54 \mathrm{E}+01$ & $2.88 \mathrm{E}+01$ & $1.92 \mathrm{E}+01$ & $1.33 \mathrm{E}+01$ & $1.03 \mathrm{E}+01$ \\
\hline 5029.1 & $5.60 \mathrm{E}+01$ & $4.99 \mathrm{E}+01$ & $4.32 \mathrm{E}+01$ & $3.35 \mathrm{E}+01$ & $2.68 \mathrm{E}+01$ & $1.70 \mathrm{E}+01$ & $1.07 \mathrm{E}+01$ & $7.43 \mathrm{E}+00$ \\
\hline 10,171 & $5.57 \mathrm{E}+01$ & $4.96 \mathrm{E}+01$ & $4.28 \mathrm{E}+01$ & $3.32 \mathrm{E}+01$ & $2.65 \mathrm{E}+01$ & $1.67 \mathrm{E}+01$ & $1.03 \mathrm{E}+01$ & $6.99 \mathrm{E}+00$ \\
\hline
\end{tabular}


Table 5 Capacitance $\left(C_{\mathrm{p}}, \mathrm{pF}\right)$ varies with frequency $(f)$ and salinity $(S)$

\begin{tabular}{|c|c|c|c|c|c|c|c|c|}
\hline \multirow[t]{2}{*}{$f, \mathrm{~Hz}$} & \multicolumn{8}{|l|}{$S, \mathrm{~g} / \mathrm{L}$} \\
\hline & 1.5625 & 3.125 & 6.25 & 12.5 & 25 & 50 & 100 & 200 \\
\hline 4 & $8.31 \mathrm{E}+03$ & $1.95 \mathrm{E}+04$ & $4.32 \mathrm{E}+04$ & $8.23 \mathrm{E}+04$ & $1.36 \mathrm{E}+05$ & $2.13 \mathrm{E}+05$ & $3.03 \mathrm{E}+05$ & $3.43 \mathrm{E}+05$ \\
\hline 6.1 & $4.75 \mathrm{E}+03$ & $1.16 \mathrm{E}+04$ & $2.70 \mathrm{E}+04$ & $5.52 \mathrm{E}+04$ & $9.69 \mathrm{E}+04$ & $1.57 \mathrm{E}+05$ & $2.28 \mathrm{E}+05$ & $2.60 \mathrm{E}+05$ \\
\hline 9.8 & $2.43 \mathrm{E}+03$ & $6.24 \mathrm{E}+03$ & $1.53 \mathrm{E}+04$ & $3.35 \mathrm{E}+04$ & $6.39 \mathrm{E}+04$ & $1.08 \mathrm{E}+05$ & $1.65 \mathrm{E}+05$ & $1.87 \mathrm{E}+05$ \\
\hline 15.6 & $1.20 \mathrm{E}+03$ & $3.21 \mathrm{E}+03$ & $8.28 \mathrm{E}+03$ & $1.93 \mathrm{E}+04$ & $3.98 \mathrm{E}+04$ & $7.30 \mathrm{E}+04$ & $1.17 \mathrm{E}+05$ & $1.34 \mathrm{E}+05$ \\
\hline 25 & $5.73 \mathrm{E}+02$ & $1.60 \mathrm{E}+03$ & $4.29 \mathrm{E}+03$ & $1.05 \mathrm{E}+04$ & $2.35 \mathrm{E}+04$ & $4.62 \mathrm{E}+04$ & $8.07 \mathrm{E}+04$ & $9.23 \mathrm{E}+04$ \\
\hline 39.9 & $2.68 \mathrm{E}+02$ & $7.66 \mathrm{E}+02$ & $2.12 \mathrm{E}+03$ & $5.42 \mathrm{E}+03$ & $1.28 \mathrm{E}+04$ & $2.75 \mathrm{E}+04$ & $5.27 \mathrm{E}+04$ & $6.14 \mathrm{E}+04$ \\
\hline 63.9 & $1.23 \mathrm{E}+02$ & $3.61 \mathrm{E}+02$ & $1.03 \mathrm{E}+03$ & $2.67 \mathrm{E}+03$ & $6.66 \mathrm{E}+03$ & $1.53 \mathrm{E}+04$ & $3.18 \mathrm{E}+04$ & $3.83 \mathrm{E}+04$ \\
\hline 102.1 & $5.53 \mathrm{E}+01$ & $1.66 \mathrm{E}+02$ & $4.86 \mathrm{E}+02$ & $1.29 \mathrm{E}+03$ & $3.30 \mathrm{E}+03$ & $7.97 \mathrm{E}+03$ & $1.78 \mathrm{E}+04$ & $2.25 \mathrm{E}+04$ \\
\hline 163.3 & $2.46 \mathrm{E}+01$ & $7.53 \mathrm{E}+01$ & $2.26 \mathrm{E}+02$ & $6.12 \mathrm{E}+02$ & $1.60 \mathrm{E}+03$ & $3.96 \mathrm{E}+03$ & $9.35 \mathrm{E}+03$ & $1.25 \mathrm{E}+04$ \\
\hline 261.1 & $1.08 \mathrm{E}+01$ & $3.36 \mathrm{E}+01$ & $1.03 \mathrm{E}+02$ & $2.85 \mathrm{E}+02$ & $7.58 \mathrm{E}+02$ & $1.92 \mathrm{E}+03$ & $4.68 \mathrm{E}+03$ & $6.86 \mathrm{E}+03$ \\
\hline 417.6 & $4.80 \mathrm{E}+00$ & $1.48 \mathrm{E}+01$ & $4.64 \mathrm{E}+01$ & $1.31 \mathrm{E}+02$ & $3.55 \mathrm{E}+02$ & $9.08 \mathrm{E}+02$ & $2.28 \mathrm{E}+03$ & $3.80 \mathrm{E}+03$ \\
\hline 1,708 & $4.50 \mathrm{E}-01$ & $1.26 \mathrm{E}+00$ & $3.99 \mathrm{E}+00$ & $1.17 \mathrm{E}+01$ & $3.35 \mathrm{E}+01$ & $8.97 \mathrm{E}+01$ & $2.34 \mathrm{E}+02$ & $7.68 \mathrm{E}+02$ \\
\hline 4368.4 & $1.20 \mathrm{E}-01$ & $2.70 \mathrm{E}-01$ & $7.80 \mathrm{E}-01$ & $2.26 \mathrm{E}+00$ & $6.57 \mathrm{E}+00$ & $1.81 \mathrm{E}+01$ & $4.83 \mathrm{E}+01$ & $2.72 \mathrm{E}+02$ \\
\hline 17,867 & $4.00 \mathrm{E}-02$ & $5.00 \mathrm{E}-02$ & $8.00 \mathrm{E}-02$ & $1.70 \mathrm{E}-01$ & $4.50 \mathrm{E}-01$ & $1.16 \mathrm{E}+00$ & $3.11 \mathrm{E}+00$ & $4.99 \mathrm{E}+01$ \\
\hline 32,895 & $4.00 \mathrm{E}-02$ & $4.00 \mathrm{E}-02$ & $4.00 \mathrm{E}-02$ & $4.00 \mathrm{E}-02$ & $7.00 \mathrm{E}-02$ & $8.00 \mathrm{E}-02$ & $1.20 \mathrm{E}-01$ & $2.05 \mathrm{E}+01$ \\
\hline 45,695 & $3.00 \mathrm{E}-02$ & $3.00 \mathrm{E}-02$ & $3.00 \mathrm{E}-02$ & $1.00 \mathrm{E}-02$ & $-2.00 \mathrm{E}-02$ & $-1.60 \mathrm{E}-01$ & $-5.80 \mathrm{E}-01$ & $1.16 \mathrm{E}+01$ \\
\hline 186,900 & $3.00 \mathrm{E}-02$ & $2.00 \mathrm{E}-02$ & $1.00 \mathrm{E}-02$ & $-3.00 \mathrm{E}-02$ & $-1.20 \mathrm{E}-01$ & $-4.40 \mathrm{E}-01$ & $-1.35 \mathrm{E}+00$ & $-1.81 \mathrm{E}+00$ \\
\hline 764,420 & $3.00 \mathrm{E}-02$ & $2.00 \mathrm{E}-02$ & $1.00 \mathrm{E}-02$ & $-3.00 \mathrm{E}-02$ & $-1.20 \mathrm{E}-01$ & $-4.30 \mathrm{E}-01$ & $-1.25 \mathrm{E}+00$ & $-2.94 \mathrm{E}+00$ \\
\hline $1,955,000$ & $2.00 \mathrm{E}-02$ & $2.00 \mathrm{E}-02$ & $1.00 \mathrm{E}-02$ & $-3.00 \mathrm{E}-02$ & $-1.20 \mathrm{E}-01$ & $-4.00 \mathrm{E}-01$ & $-1.09 \mathrm{E}+00$ & $-2.44 \mathrm{E}+00$ \\
\hline $3,126,500$ & $2.00 \mathrm{E}-02$ & $2.00 \mathrm{E}-02$ & $1.00 \mathrm{E}-02$ & $-3.00 \mathrm{E}-02$ & $-1.20 \mathrm{E}-01$ & $-3.90 \mathrm{E}-01$ & $-9.40 \mathrm{E}-01$ & $-1.92 \mathrm{E}+00$ \\
\hline $5,000,000$ & $2.00 \mathrm{E}-02$ & $2.00 \mathrm{E}-02$ & $0.00 \mathrm{E}+00$ & $-3.00 \mathrm{E}-02$ & $-1.30 \mathrm{E}-01$ & $-3.70 \mathrm{E}-01$ & $-7.40 \mathrm{E}-01$ & $-1.32 \mathrm{E}+00$ \\
\hline
\end{tabular}

The experiments with the capacitor filled with sand saturated with $\mathrm{NaCl}$ solution in a plastic container also show the same rule. From Fig. 10, it can be seen that the capacitance is also approximately inversely proportional to the square of the distance between plates.

The six curves in Fig. 10 were tested at six different frequencies. In fact, from $4 \mathrm{~Hz}$ to $5 \mathrm{MHz}$, we recorded 100 groups of capacitance data, and each group shows the inversely proportional relationship between the capacitance and the square of the distance.

In the above experiments, the dielectrics are fresh water, saline solution, or sand mixed with saline solution, which have different salinities and different saturations. We can see that whether the measurement was carried out in a PVC pipe or in a plastic container, and whether the measured dielectric is liquid or solid, all of the results indicate that the capacitance is approximately inversely proportional to the square of the distance between plates. Such phenomenon may be related to the polarization and relaxation processes. As early as 1929, Debye assumed that the dipole relaxation of a dielectric is a purely viscous process without elastic forces, and established an equation to describe the relationship of the dielectric constant and the angular frequency as shown in Eq. (5) (Debye 1929). In 1941, K. S.
Cole and R. H. Cole found that the relaxation of most solid dielectrics does not satisfy the Debye model. They corrected the Debye model by taking into account the electrical conductance, and they proposed the so-called ColeCole model, as shown in Eq. (6)

$\varepsilon^{*}(\omega)=\varepsilon_{\infty}+\frac{\varepsilon_{\mathrm{s}}-\varepsilon_{\infty}}{1+i \omega \tau}$

$\varepsilon^{*}(\omega)=\varepsilon_{\infty}+\frac{\varepsilon_{\mathrm{s}}-\varepsilon_{\infty}}{1+(i \omega \tau)^{1-\alpha}}$,

where, $\varepsilon_{\infty}$ is the optical frequency dielectric constant, $\varepsilon_{\mathrm{S}}$ is the static dielectric constant, $i=\sqrt{-1}, \tau$ is the time constant, and $\alpha$ is the empirical coefficient, $0<\alpha<1$.

The above two and other models, such as LorentzLorenz, Maxwell-Wagner, and Onsager models, describe the dielectric constant of isolated material. In our experiment, the medium is a mixture of conductive materials, such as $\mathrm{Na}^{+}, \mathrm{Cl}^{-}$, and other cations or anions, and insulating matter, such as water and hydrocarbon molecules. In the pores of rocks, the conductive and non-conductive materials coexist, and in most cases, they can form numerous micro capacitors, that is the micro ion capacitor mentioned before. Obviously, the inversely proportional relationship between ionic capacitance and the square of 
Table 6 Resistance $\left(R_{\mathrm{p}}, \Omega\right)$ varies with frequency $(f)$ and salinity $(S)$

\begin{tabular}{|c|c|c|c|c|c|c|c|c|}
\hline \multirow[t]{2}{*}{$f, \mathrm{~Hz}$} & \multicolumn{8}{|l|}{$S, \mathrm{~g} / \mathrm{L}$} \\
\hline & 1.5625 & 3.125 & 6.25 & 12.5 & 25 & 50 & 100 & 200 \\
\hline 4 & $7.94 \mathrm{E}+02$ & $4.66 \mathrm{E}+02$ & $2.83 \mathrm{E}+02$ & $1.88 \mathrm{E}+02$ & $1.27 \mathrm{E}+02$ & $8.73 \mathrm{E}+01$ & $6.52 \mathrm{E}+01$ & $6.10 \mathrm{E}+01$ \\
\hline 6.1 & $7.64 \mathrm{E}+02$ & $4.42 \mathrm{E}+02$ & $2.62 \mathrm{E}+02$ & $1.70 \mathrm{E}+02$ & $1.14 \mathrm{E}+02$ & $7.87 \mathrm{E}+01$ & $5.86 \mathrm{E}+01$ & $5.46 \mathrm{E}+01$ \\
\hline 9.8 & $7.40 \mathrm{E}+02$ & $4.20 \mathrm{E}+02$ & $2.44 \mathrm{E}+02$ & $1.54 \mathrm{E}+02$ & $1.01 \mathrm{E}+02$ & $6.93 \mathrm{E}+01$ & $5.15 \mathrm{E}+01$ & $4.78 \mathrm{E}+01$ \\
\hline 15.6 & $7.21 \mathrm{E}+02$ & $4.03 \mathrm{E}+02$ & $2.30 \mathrm{E}+02$ & $1.40 \mathrm{E}+02$ & $8.98 \mathrm{E}+01$ & $6.05 \mathrm{E}+01$ & $4.46 \mathrm{E}+01$ & $4.12 \mathrm{E}+01$ \\
\hline 25 & $7.09 \mathrm{E}+02$ & $3.92 \mathrm{E}+02$ & $2.19 \mathrm{E}+02$ & $1.30 \mathrm{E}+02$ & $8.05 \mathrm{E}+01$ & $5.29 \mathrm{E}+01$ & $3.81 \mathrm{E}+01$ & $3.54 \mathrm{E}+01$ \\
\hline 39.9 & $7.00 \mathrm{E}+02$ & $3.83 \mathrm{E}+02$ & $2.12 \mathrm{E}+02$ & $1.23 \mathrm{E}+02$ & $7.38 \mathrm{E}+01$ & $4.68 \mathrm{E}+01$ & $3.25 \mathrm{E}+01$ & $3.02 \mathrm{E}+01$ \\
\hline 63.9 & $6.94 \mathrm{E}+02$ & $3.78 \mathrm{E}+02$ & $2.07 \mathrm{E}+02$ & $1.18 \mathrm{E}+02$ & $6.92 \mathrm{E}+01$ & $4.24 \mathrm{E}+01$ & $2.83 \mathrm{E}+01$ & $2.60 \mathrm{E}+01$ \\
\hline 102.1 & $6.91 \mathrm{E}+02$ & $3.74 \mathrm{E}+02$ & $2.03 \mathrm{E}+02$ & $1.15 \mathrm{E}+02$ & $6.61 \mathrm{E}+01$ & $3.94 \mathrm{E}+01$ & $2.53 \mathrm{E}+01$ & $2.31 \mathrm{E}+01$ \\
\hline 163.3 & $6.88 \mathrm{E}+02$ & $3.71 \mathrm{E}+02$ & $2.01 \mathrm{E}+02$ & $1.13 \mathrm{E}+02$ & $6.40 \mathrm{E}+01$ & $3.75 \mathrm{E}+01$ & $2.33 \mathrm{E}+01$ & $2.10 \mathrm{E}+01$ \\
\hline 261.1 & $6.86 \mathrm{E}+02$ & $3.70 \mathrm{E}+02$ & $1.99 \mathrm{E}+02$ & $1.11 \mathrm{E}+02$ & $6.27 \mathrm{E}+01$ & $3.63 \mathrm{E}+01$ & $2.20 \mathrm{E}+01$ & $1.96 \mathrm{E}+01$ \\
\hline 417.6 & $6.85 \mathrm{E}+02$ & $3.69 \mathrm{E}+02$ & $1.98 \mathrm{E}+02$ & $1.10 \mathrm{E}+02$ & $6.17 \mathrm{E}+01$ & $3.54 \mathrm{E}+01$ & $2.12 \mathrm{E}+01$ & $1.86 \mathrm{E}+01$ \\
\hline 1,708 & $6.84 \mathrm{E}+02$ & $3.67 \mathrm{E}+02$ & $1.97 \mathrm{E}+02$ & $1.09 \mathrm{E}+02$ & $6.03 \mathrm{E}+01$ & $3.42 \mathrm{E}+01$ & $2.00 \mathrm{E}+01$ & $1.64 \mathrm{E}+01$ \\
\hline 4368.4 & $6.83 \mathrm{E}+02$ & $3.67 \mathrm{E}+02$ & $1.96 \mathrm{E}+02$ & $1.08 \mathrm{E}+02$ & $6.00 \mathrm{E}+01$ & $3.39 \mathrm{E}+01$ & $1.97 \mathrm{E}+01$ & $1.52 \mathrm{E}+01$ \\
\hline 17,867 & $6.83 \mathrm{E}+02$ & $3.67 \mathrm{E}+02$ & $1.96 \mathrm{E}+02$ & $1.08 \mathrm{E}+02$ & $5.98 \mathrm{E}+01$ & $3.37 \mathrm{E}+01$ & $1.95 \mathrm{E}+01$ & $1.38 \mathrm{E}+01$ \\
\hline 32,895 & $6.82 \mathrm{E}+02$ & $3.67 \mathrm{E}+02$ & $1.96 \mathrm{E}+02$ & $1.08 \mathrm{E}+02$ & $5.98 \mathrm{E}+01$ & $3.37 \mathrm{E}+01$ & $1.95 \mathrm{E}+01$ & $1.34 \mathrm{E}+01$ \\
\hline 45,695 & $6.82 \mathrm{E}+02$ & $3.66 \mathrm{E}+02$ & $1.96 \mathrm{E}+02$ & $1.08 \mathrm{E}+02$ & $5.98 \mathrm{E}+01$ & $3.36 \mathrm{E}+01$ & $1.95 \mathrm{E}+01$ & $1.32 \mathrm{E}+01$ \\
\hline 186,900 & $6.80 \mathrm{E}+02$ & $3.66 \mathrm{E}+02$ & $1.96 \mathrm{E}+02$ & $1.08 \mathrm{E}+02$ & $5.98 \mathrm{E}+01$ & $3.37 \mathrm{E}+01$ & $1.95 \mathrm{E}+01$ & $1.29 \mathrm{E}+01$ \\
\hline 764,420 & $6.74 \mathrm{E}+02$ & $3.64 \mathrm{E}+02$ & $1.95 \mathrm{E}+02$ & $1.08 \mathrm{E}+02$ & $5.99 \mathrm{E}+01$ & $3.39 \mathrm{E}+01$ & $1.99 \mathrm{E}+01$ & $1.33 \mathrm{E}+01$ \\
\hline $1,955,000$ & $6.56 \mathrm{E}+02$ & $3.57 \mathrm{E}+02$ & $1.93 \mathrm{E}+02$ & $1.07 \mathrm{E}+02$ & $5.98 \mathrm{E}+01$ & $3.46 \mathrm{E}+01$ & $2.15 \mathrm{E}+01$ & $1.58 \mathrm{E}+01$ \\
\hline $3,126,500$ & $6.31 \mathrm{E}+02$ & $3.47 \mathrm{E}+02$ & $1.89 \mathrm{E}+02$ & $1.05 \mathrm{E}+02$ & $5.96 \mathrm{E}+01$ & $3.55 \mathrm{E}+01$ & $2.38 \mathrm{E}+01$ & $1.98 \mathrm{E}+01$ \\
\hline $5,000,000$ & $5.74 \mathrm{E}+02$ & $3.22 \mathrm{E}+02$ & $1.78 \mathrm{E}+02$ & $1.01 \mathrm{E}+02$ & $5.86 \mathrm{E}+01$ & $3.75 \mathrm{E}+01$ & $2.85 \mathrm{E}+01$ & $2.92 \mathrm{E}+01$ \\
\hline
\end{tabular}

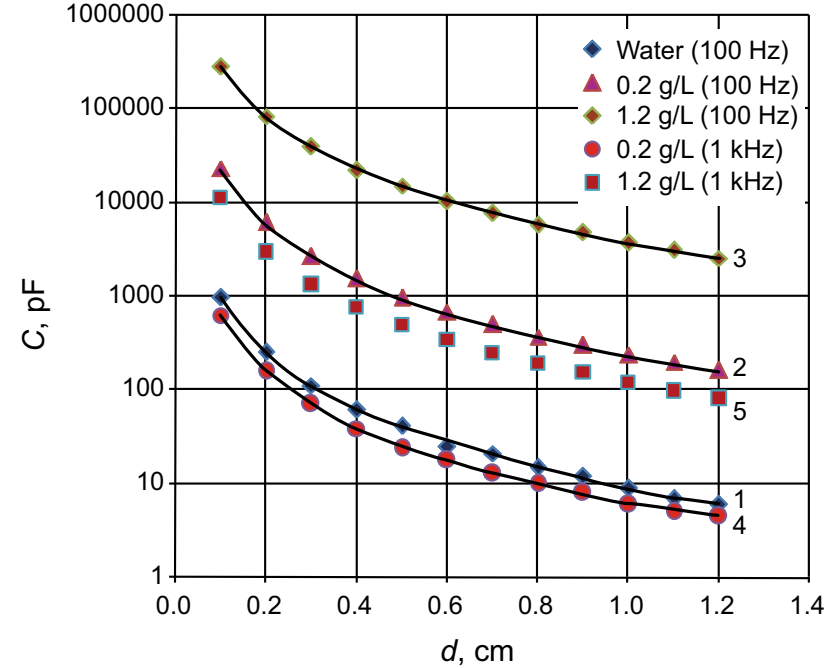

Fig. 9 The relationship of $\mathrm{NaCl}$ solution's capacitance and the distance between plates at different salinities and frequencies. The capacitance increases with increasing salinity and decreasing frequency, and decreases with the increase of the square of the distance. $1 . C_{\mathrm{p}}=$ 9.2428d $d^{-2.0048}, R^{2}=0.9987 ; 2 . C_{\mathrm{p}}=243.92 d^{-1.9980}, R^{2}=0.9998 ; 3$. $C_{\mathrm{p}}=3841.50 d^{-1.9038}, R^{2}=0.9992 ; \quad 4 . \quad C_{\mathrm{p}}=6.2724 d^{-2.009}, R^{2}=$ 0.9996; 5. $C_{\mathrm{p}}=122.11 d^{-1.981}, R^{2}=0.9997$

the distance cannot be explained by either the Debye model or the Cole-Cole model. We should create a novel model to explain this rule.

\subsection{Preliminary explanation}

The main reason of this remarkable phenomenon is that in the pores and fractures, especially in tight oil and shale gas zones, various ions, water molecules, and hydrocarbon molecules can form numerous micro ion capacitors, which will parallel or series connect with each other. Compared with conventional capacitors, the outstanding characteristic of this micro capacitor is that the length of the plates nearly equals the distance between the plates. The parameter $A$ is the surface area of the ion, and the distance $d$ is the diameter of water or hydrocarbon molecules.

For the micro ion capacitor mentioned above, if one or several water molecules are dielectric, and $\mathrm{Na}^{+}$and $\mathrm{Cl}^{-}$or other cations and anions are plates, the distance between plates almost equals the size of ionic plates. Then the capacitance of micro ion capacitor also accords with the rule as shown in Eq. (3). The diameter of a water molecular is about $4 \AA$, and we can estimate the capacitance of such a micro ion capacitor as follows:

$$
\begin{aligned}
C_{\mathrm{Na}^{+}} & =\epsilon \frac{A}{d^{2}}=\epsilon \frac{\pi r^{2}}{d^{2}}=\epsilon \frac{\pi(1.81 / 2)^{2}}{(4+0.95 / 2+1.81 / 2)^{2}} \\
& =0.088851 \epsilon
\end{aligned}
$$


Fig. 10 The relationship between capacitance and the distance between two plates at different frequencies. The figure illustrates the increase of the capacitance with decreasing frequency, and the increase with a decrease in the square of the distance, which is different from conventional capacitors

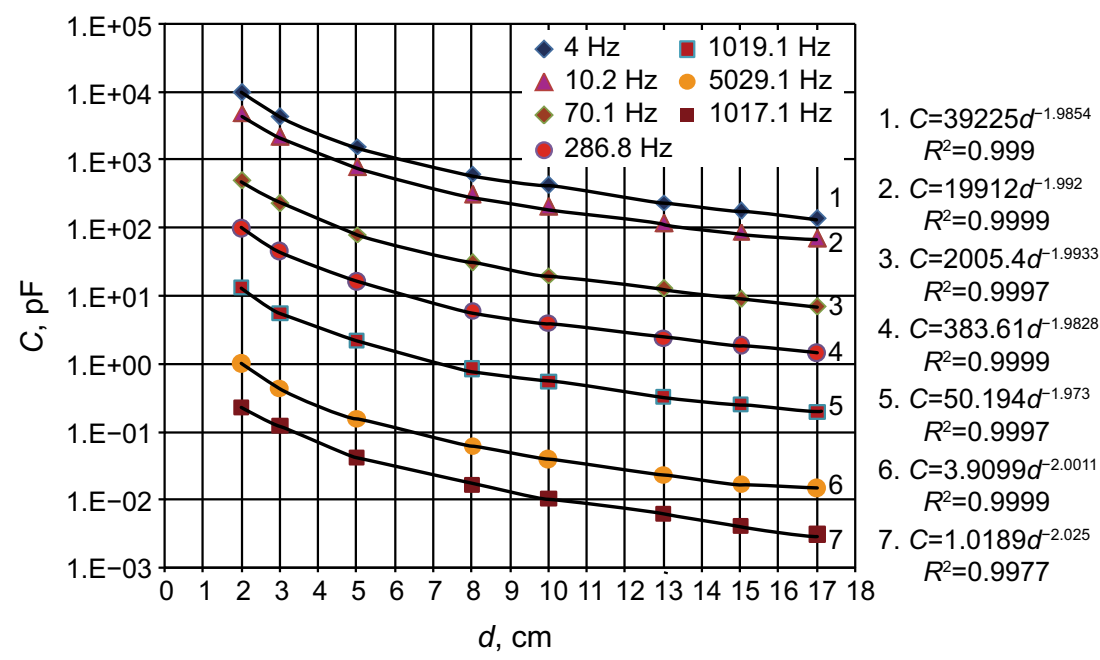

$$
\begin{aligned}
C_{\mathrm{Cl}^{-}} & =\epsilon \frac{A}{d^{2}}=\epsilon \frac{\pi r^{2}}{d^{2}}=\epsilon \frac{\pi(0.95 / 2)^{2}}{(4+0.95 / 2+1.81 / 2)^{2}} \\
& =0.024477 \epsilon
\end{aligned}
$$

According to the theoretical value estimated in Eq. (1), the value of micro capacitivity $\epsilon$ can be calculated:

$\epsilon_{\mathrm{Na}^{+}}=1.80 \times 10^{-6} \mathrm{pF}$,

$\epsilon_{\mathrm{Cl}^{-}}=6.54 \times 10^{-6} \mathrm{pF}$,

Because the different diameters of $\mathrm{Na}^{+}$and $\mathrm{Cl}^{-}$, the micro capacitivity $\epsilon$ varies from $1.8 \times 10^{-6}$ to $6.54 \times$ $10^{-6} \mathrm{pF}$.

For capacitors with liquid and solid dielectrics, many aspects remain unclear, especially the mechanisms of polarization and relaxation. The reasons may be related to the single ionic capacitors formed between free $\mathrm{Na}^{+}$and $\mathrm{Cl}^{-}$ions in the non-conductive liquid or solid molecules, and the single ionic capacitors are connected in series or parallel. However, the distance between molecules in a gas dielectric or vacuum dielectric capacitor is too long to form a microscopic capacitor. This may be the important reason for the remarkable difference between these two types of capacitors. Another reason may be the complexity of channels for ion transportation (Ma et al. 2014).

\section{Conclusions}

We measured the capacitance and resistance of non-gas dielectrics in a PVC pipe and a plastic container, and the experimental results illustrated an unusual rule in the ionic capacitance of fluid or solid dielectrics. Although many models have been established, there are still many problems about the polarization and relaxation of the ions or molecules under the external EMF that are not solved. A novel concept and a model, single micro ion capacitor, are first proposed in this paper. Based on the experimental results, we found that:

(1) The ionic capacitance is inversely proportional to the square of the distance, which remarkably differs from that of parallel plate capacitors with air dielectric;

(2) Compared with conventional capacitors, the outstanding characteristic of a micro ion capacitor is that the length of the plate nearly equals the distance between the plates;

(3) Based on the micro ion capacitor model, the micro capacitivity $\epsilon$ varies from $1.8 \times 10^{-6}$ to $6.54 \times$ $10^{-6} \mathrm{pF}$.

Such phenomenon may be also related to the relatively complex polarization and relaxation mechanisms of the numerous single micro ion capacitors, and another important reason may be the tortuosity of the ion conductive path in porous solid media, which will be discussed later.

Acknowledgments The authors are grateful for the financial support from Basic Science Program of Advanced Well Logging Technology of CNPC (2014A-2319) and support from the Science and Technology Program (G12-3) of State Key Laboratory of Oil and Gas Reservoir Geology and Exploitation of SWPU (Southwest Petroleum University).

Open Access This article is distributed under the terms of the Creative Commons Attribution License which permits any use, distribution, and reproduction in any medium, provided the original author(s) and the source are credited.

\section{References}

Asami K. Characterization of heterogeneous systems by dielectric spectroscopy. Prog Polym Sci. 2002;27(8):1617-59.

Chelidze TL, Gueguen Y. Electrical spectroscopy of porous rocks: a review-I. Theoretical model. Geophys J Int. 1999;137(1):1-15. 
Chelidze TL, Gueguen Y, Ruffet C. Electrical spectroscopy of porous rocks: a review-II. Experimental results and interpretation. Geophys J Int. 1999;137(1):16-34.

Clark B, Allen DF, Best DL, et al. Electromagnetic propagation logging while drilling: theory and experiment. 1990. SPE 18117-PA.

Clavier C, Coates G, Dumanoir J. Theoretical and experimental bases for the dual-water model for interpretation of shaly sands. Soc Petrol Eng J. 1984;24:153-68.

Cole KS, Cole RH. Dispersion and absorption in dielectrics. J Chem Phys. 1941;9(4):341-51.

Davidson DW, Cole RH. Dielectric relaxation in glycerine. J Chem Phys. 1950;18(10):1417.

Davidson DW, Cole RH. Dielectric relaxation in glycerol, propylene glycol and $n$-propanol. J Chem Phys. 1951;19(12):1484-90.

Debye PW. Polar molecules. New York: Chemical Catalog Co.; 1929.

Dong XB, Wang YH. A broadband dielectric measurement technique: theory, experimental verification, and application. J Environ Eng Geophys. 2009;14(1):25-38.

Endres AL, Bertrand EA. A pore-size scale model for the dielectric properties of water-saturated clean rocks and soils. Geophysics. 2006;71:F185-93.

Freedman R, Vogiatzis JP. Theory of microwave dielectric constant logging using the electromagnetic wave propagation method. Geophysics. 1979;44(5):969-86.

Gasparrini M, Sassi W, Gale JFW. Natural sealed fractures in mudrocks: a case study tied to burial history from the Barnett Shale, Fort Worth Basin, Texas, USA. Mar Petrol Geol. 2014;55:122-41.

Ghanizadeh A, Gasparik M, Amann-Hildenbrand A, et al. Experimental study of fluid transport processes in the matrix system of the European organic-rich shales: I. Scandinavian Alum Shale. Mar Pet Geol. 2014;51:79-99.

Glover PWJ, Gomez JB, Meredith PG, et al. Modelling the stressstrain behavior of saturated rocks undergoing triaxial deformation using complex electrical conductivity measurements. Surv Geophys. 1996;17(3):307-30.

Glover PWJ, Meredith PG, Sammonds PR, et al. Ionic surface electrical conductivity in sandstone. J Geophys Res. 1994;99(B11):21635-50.

Glover PWJ, Meredith PG, Sammonds PR, et al. Measurements of complex electrical conductivity and fluid permeabilities in porous rocks at raised confining pressures. Rock Mechanics in Petroleum Engineering. Delft, Netherlands. 29-31 August 1994b. pp. 29-36.
Hamada GM, Al-Awad MNJ. Petrophysical evaluation of low resistivity sandstone reservoirs. International Symposium of Core Analysts. The Hague. 14-16 Sept 1998.

Hassoun TH, Zainalabedin K, Minh CC. Hydrocarbon detection in low contrast resistivity pay zones, capillary pressure and ROS determination with NMR logging in Saudi Arabia. SPE Paper 37770. 10th MEOS, Bahrain. 15-18 March 1997.

Havriliak S, Negami S. A complex plane analysis of $\alpha$-dispersions in some polymer systems. J Polym Sci Part C. 1966;14(1):99-117.

Hilfer R, Prigogine I, Rice SA. Transport and relaxation phenomena in porous media. Adv Chem Phys. 1995;92:299.

Hilfer R, Widjajakusuma J, Biswal B. Macroscopic dielectric constant for microstructures of sedimentary rocks. Granular Matter 2. Berlin: Springer-Verlag; 1999. pp. 137-41.

Jonscher AK. Dielectric relaxation in solids. London: Chelsea Press; 1983. pp. 219-26.

Jonscher AK. Dielectric relaxation in solids. J Phys D. 1999;32:57-70.

Knight RJ, Nur A. The dielectric constant of sandstones, $60 \mathrm{kHz}$ to 4MHz. Geophysics. 1987;52(5):644-54.

Lesmes DP, Morgan FD. Dielectric spectroscopy of sedimentary rocks. J Geophys Res. 2001;106(B7):13329-46.

Lockner DA, Byerlee JD. Complex resistivity measurements of confined rock. J Geophys Res. 1985;90:7837-47.

Ma JS, Sanchez JP, Wu KJ, et al. A pore network model for simulating non-ideal gas flow in micro- and nano-porous materials. Fuel. 2014;116(15):498-508.

Nover G, Heikamp S, Freund D. Electrical impedance spectroscopy used as a tool for the detection of fractures in rock samples exposed to either hydrostatic or triaxial pressure conditions. Nat Hazards. 2000;21(2-3):317-30.

Ruffett C, Gueguen Y, Darot M. Complex conductivity measurements and fractal nature of porosity. Geophysics. 1991;56(6):758-68.

Toumelin E, Torres-Verdin C. Pore-scale simulation of kHz-GHz electromagnetic dispersion of rocks: effects of rock morphology, pore connectivity, and electrical double layers. In: SPLWA 50th Annual Logging Symposium. 21-24 Jun 2009.

Waxman MH, Smits LJM. Electrical conductivities in oil-bearing shaly sands. Soc Petrol Eng J. 1968;8(2):107-22.

Zemanek J. Low-resistivity hydrocarbon-bearing sand reservoirs. SPE Form Eval. SPE-15713-PA. 1989;4(4):515-21. 